\title{
TRANSFORMASI AKAD TABARRU' MENJADI AKAD MU'AWADHAT; ANALISIS AKAD HIWALAH DAN AKAD KAFALAH DI LEMBAGA KEUANGAN SYARIAH
}

\author{
Muhamad Izazi Nurjaman dan Doli Witro \\ Universitas Islam Negeri Sunan Gunung Djati Bandung \\ Email: muhamadizazinurjaman@gmail.com dandoliwitro01@gmail.com
}

\begin{abstract}
This study discusses the transformation of tabarru' contracts into mu'awadhat contracts, especially in hiwalah and kafalah contracts at Islamic Financial Institutions (LKS). This article uses a descriptive analysis method that is bibliographic in nature. This study aims to find facts about changes in the status of the contract and its position can be known by looking at and analyzing its practice in the field, especially in LKS. This article uses qualitative research methods that are library research. Data analysis techniques used are data reduction, data presentation, and drawing conclusions. The results of the analysis show that there is a transformation of the tabarru' contract (hiwalah and kafalah) into a mu'awadhat contract (hiwalah bi al-ujrah and kafalah bia al-ujrah in LKS and has been regulated in the DSN/MUI fatwa. LKS and Customers) by taking into account the provisions of the texts, the opinions of the scholars and the level of benefit that do not conflict with sharia economic principles.
\end{abstract}

Keywords: Transformation of Akad, Hiwalah, Kafalah, Syari'ah Financial Institutions.

\begin{abstract}
Abstrak
Penelitian ini membahas transformasi akad tabarru' menjadi akad mu'awadhat khususnya pada akad hiwalah dan kafalah di Lembaga Keuangan Syariah (LKS). Artikel ini menggunakan metode deskriptif analisis yang bersifat kepustakaan. Penelitian bertujuan untuk menemukan fakta akan perubahan pada status akad tersebut dan kedudukannya dapat diketahui dengan melihat dan menganalisis praktiknya di lapangan khususnya di LKS. Artikel ini menggunakan metode penelitian kualitatif yang bersifat kepustakaan (library research). Teknik analisis data yang digunakan adalah reduksi data, penyajian data, dan penarikan kesimpulan. Hasil analisis menunjukkan bahwa terdapat transformasi akad tabarru' (hiwalah dan kafalah) menjadi akad mu'awadhat (hiwalah bi al-ujrah dan kafalah bia al-ujrah di LKS dan telah diatur dalam fatwa DSN/MUI. Penetapan fatwa tersebut berlandaskan kepada kebutuhan masyarakat (LKS dan Nasabah) dengan memperhatikan ketentuan nash, pendapat para ulama dan tingkat kemaslahatan yang tidak bertentangan dengan prinsip ekonomi syariah.
\end{abstract}

Kata Kunci: Transformasi Akad, Hiwalah, Kafalah, Lembaga Keuangan Syari'ah. 


\section{PENDAHULUAN}

Pendahuluan berisi tentang latar belakang Akad atau perjanjian merupakan sebuah pernyataan permintaan (ijab) dan penerimaan (qabul) yang berpengaruh terhadap sebuah objek perikatan (Hasan, 2018). Sehingga dengan sebuah akad akan melahirkan hak dan kewajiban di antara para pihak. Seorang yang beragama Islam (Muslim) ketika hendak transaksi muamalah harus memperhatikan rukun, syarat, dan bentuk transaksi yang diperbolehkan dalam ajaran Islam (Riyadi \& Hilyatin, 2021; Witro, 2019). Satu di antaranya adalah akad. Dengan akad para pihak akan melakukan atau tidak melakukan sesuatu sebagaimana ketentuan yang disepakati bersama. Maka secara tidak langsung, akad atau transaksi menjadi Undang-Undang bagi para pihak sebagaimana yang disebutkan dalam pasal 1338 Kitab Undang-Undang Hukum Perdata.

Berdasarkan tujuannya akad terbagi menjadi dua, yaitu: Pertama, akad mu'awadhat yaitu akad yang dilakukan dengan tujuan untuk memperoleh keuntungan. Adapun yang termasuk akad ini adalah akad pertukaran (jual beli, ijarah dan ju'alah) dan akad penyertaan (musyarakah, mudharabah, musaqah, muzaraah dan mukhabarah, mugharasah, qismah, dan muhaya'ah). Kedua, akad tabarru' yaitu akad yang dilakukan dengan tujuan membantu pihak lain (Mubarok \& Hasanudin, 2017a). Adapun yang termasuk akad ini adalah akad pemberian (hibah, wasiat, wakaf, luqhatah, al-hajr, zakat, sedekah dan al-shulh) dan akad utang piutang (wadi'ah, 'ariyah, qardh, hiwalah, rahn dan al-ibra') serta akad penyerahan diri (wakalah dan kafalah).

Berkaitan dengan akad tabarru' yang bersifat utang piutang adalah pemindahan utang (hiwalah) dan penjaminan utang (kafalah). Kedua akad ini bersifat tolong menolong dalam jangka waktu mendesak. Artinya, pihak yang ditolong tetap memiliki kewajiban membayar utang kepada pihak yang menolong tersebut (Syahpawi, 2012). Namun sejatinya kedua akad tersebut menyelamatkan pihak yang memiliki utang yang sudah jatuh tempo dan sudah tidak bisa membayar kewajibannya. Sehingga kedua akad ini merupakan pemindahan kewajiban membayar utang dari orang yang berutang kepada orang lain menjadi berutang kepada orang yang menolongnya membayarkan utang.

Namun dalam perkembangannya, kedua akad tersebut berubah kedudukannya menjadi sebuah akad yang bersifat mu'awadhat. Artinya, pihak yang menolong tersebut mensyaratkan sebuah imbalan terhadap jasa bantuannya tersebut. Sehingga hal itu merubah nama akad yang dilakukan. Bagi akad pemindahan utang (hiwalah) berubah menjadi akad hiwalah bi al-ujrah dan bagi akad penjaminan utang (kafalah) berubah menjadi akad kafalah bi al-ujrah. Para ulama berbeda pendapat terhadap kedudukan akad tersebut. Ada yang membolehkan ada juga yang melarang. Dengan demikian, penelitian ini membahas mengenai transformasi akad tabarru' menjadi akad mu'wadhat khususnya pada akad hiwalah dan kafalah. Penelitian bertujuan untuk menemukan fakta akan perubahan pada status akad tersebut dan kedudukannya dapat diketahui dengan melihat dan menganalisis praktiknya di lapangan khususnya di lembaga keuangan syariah (LKS).

\section{LITERATURE REVIEW}

Kajian tentang akad transformasi akad tabarru' menjadi akad mu'awadhat di Lembaga Keuangan Syariah (LKS) sudah dilakukan. Rozali (2020) tentang Transformasi Akad Perbankan Syariah dalam Pembentukan Hukum Perikatan Nasional. Hasil penelitian ini menunjukkan transformasi akad perbankan Syariah ke dalam hukum perikatan nasional berada pada tatanan konsep hukum. Sebagaimana yang tertuang dalam bentuk fatwa DSN-MUI tentang Akad Perbankan Syariah, UndangUndang Nomor 21 Tahun 2008 Tentang Perbankan Syariah, Peraturan Mahkamah Agung Nomor 2 Tahun 2008 tentang Kompilasi Hukum Ekonomi Syariah dan lain sebagainya. Akad perbankan syariah 
mempunyai ciri khusus yang berkaitan dengan rukun dan syarat perjanjian yang dilakukan kedua belah pihak dengan mencegah terjadinya riba, gharar, maisir, dan lainnya yang membatalkan (dilarang dalam Islam).

Di samping itu, Witro, Nuraeni, dan Januri (2021) tentang classification of aqad in sharia economic law. Kajian ini menjelaskan klasifikasi akad secara umum dalam hukum ekonomi syariah, di mana difokuskan kepada akad tabarru' dan akad tijarah. Transformasi akad baik akad tabarru' dan akad tijarah sudah dilakukan. Sebagaimana penelitian transformasi akad muamalah klasik dalam produk perbankan syariah yang dilakukan Aziz (2012). Dalam penelitian ini disimpulkan setidaknya ada dua metode yang dapat dilakukan dalam transformasi akad muamalah klasik dalam perbankan syariah yaitu pertama, dengan memodifikasi akad muamalah klasik secara terbatas. Hal ini bertujuan untuk membuat akad muamalah tersebut menjadi aplikatif pada ranah perbankan. Kedua, dengan cara membuat akad baru yang diderivasi dari akad klasik.

Kajian-kajian perubahan akad juga dilakukan Huda (2015), Perubahan Akad Wadi'ah. Dalam kajian ini dijelaskan perubahan akad wadi'ah secara komprehensif. Berbeda dengan kajian transformasi akad yang penulis lakukan yaitu dari akad tabarru' menjadi akad mu'wadhat khususnya pada akad hiwalah dan kafalah.

\section{METODE PENELITIAN}

Artikel ini menggunakan metode penelitian kualitatif yang bersifat kepustakaan (library research). Pendekatan yang digunakan yaitu deskriptif analitis, di mana metode ini mencoba memberikan gambaran atau penjelasan terhadap suatu objek yang menjadi fokus penelitian, kemudian menganalisis objek tersebut menjadi satu kesatuan yang terintegrasi berupa fakta dan penjelasan. Dengan demikian, penelitian ini menjelaskan transformasi akad tabarru' menjadi akad mu'awadhat khusunya akad hiwalah dan kafalah. Teknik pengumpulan data dilakukan dengan cara dokumentasi yaitu mengumpulkan dan mencari berbagai referensi dari kitab ulama klasik, buku, jurnal, dan sumber yang lainnya yang berkaitan dengan objek penelitian. Teknik analisis data yang digunakan adalah reduksi data, penyajian data, dan penarikan kesimpulan (Miles \& Huberman, 1984).

\section{KONSEP DASAR}

\section{Tinjauan Umum Akad Hiwalah Definsi dan Dasar Hukum Hiwalah}

Hiwalah secara kebahasaan memiliki makna berpindah (al-intiqal) atau memindahkan (altahwil) (Kusumastuti \& Rahmawati, 2019; Sudiarti, 2018; Witro, 2021). Selain itu juga, hiwalah dapat diartikan sebagai pemindahan dari suatu tempat kepada tempat yang lain (Al-Jaziri, n.d.). Dari definisi tersebut terdapat dua kategori, yaitu memindahkan sesuatu yang bersifat kebendaan (memindahkan barang) dan juga memindahkan sesuatu yang bersifat tanggungan (memindahkan utang) (Mubarok \& Hasanudin, 2017b). Adapun terkait hal ini, hiwalah cenderung kepada akad memindahkan utang. Sebagaimana berdasarkan istilah syara', hiwalah dalam Imam Syafi'i mengatakan bahwa "aqad pemindahan sesuatu utang dari tanggungan yang berutang kepada tanggapan orang lain". Dalam kitab Hikmah al-Tasyri' wa falsafatuhu dikatakan bahwa pengertian hiwalah adalah: pemindahan hutang dari tanggungan. Dijelaskan juga dalam (AdDardir) bahwa menurut jumhur ulama fiqh, hiwalah diartikan sebagai akad yang menghendaki pengalihan utang dari tanggungjawab seseorang kepada tanggungjawab orang lain.

Adapun menurut peristilahan, pendapat ulama mazhab dapat dikategorikan sebagai berikut: Menurut ulama Hanafiyyah, hiwalah adalah suatu akad yang memiliki tujuan untuk memindahkan utang dari tanggung jawab (satu pihak) menjadi tanggungjawab pihak lain (Al-Syarbini, 1997). Sedangkan menurut jumhur ulama, hiwalah adalah suatu akad pengalihan utang dari satu pihak yang berutang (madin) 
kepada pihak lain (penanggung) terhadap utang yang sama sehingga pihak pertama (madin) terbebas dari kewajiban membayar utang (Al-Nawawi, n.d.-a).

Akad hiwalah diperbolehkan untuk dilakukan sebagaimana merujuk kepada hadits riwayat Bukhari dari Abu Hurairah bahwasanya Rasulullah Bersabda: "Menunda pembayaran utang bagi yang mampu adalah suatu kezaliman. Apabila (utang) seorang di antara kalian dialihkan kepada pihak yang mampu, maka hendaklah ia menerimanya" (Abdurrahman, 2011). Sedangkan menurut ijma', para ulama sepakat membolehkan akad hiwalah. Adapun akad hiwalah yang diperbolehkan adalah hiwalah atas utang yang tidak berbentuk barang melainkan hiwalah yang berbentuk utang. Karena hiwalah itu merupakan pemindahan utang (berupa uang atau kewajiban finansial) (Antonio, 2018). Selain itu juga, DSN/MUI menetapkan Fatwa Nomor 58 tahun 2000 tentang Hiwalah. Adapun hikmah dibolehkannya akad hiwalah adalah memberikan kemudahan dalam bermuamalah dan menghindari pihak tertentu dari adanya kerugian.

\section{Syarat dan Rukun Hiwalah}

Akad hiwalah boleh dilakukan tentunya harus memenuhi syarat dan rukunnya. Menurut ulama Hanafiyyah rukun hiwalah hanya ijab (pernyataan hiwalah) dari muhil (pihak pertama) dan qabul (pernyataan menerima hiwalah) dari muhal (pihak kedua) kepada muhal 'alaih (pihak ketiga) (Syarqawie, 2015). Sedangkan menurut jumhur ulama rukun hiwalah terdiri dari: muhil (pihak yang memiliki utang/madin), muhal (pihak yang memberi utang/da'in/yang memiliki piutang), muhal 'alaih (pihak yang memiliki kewajiban melunasi utang muhil kepada muhal), muhal bih/dain (utang) dan shigat (ijab qabuli). Adapun terkait syarat hiwalah berpacu kepada rukun hiwalah itu sendiri antara lain (Mubarok \& Hasanudin, 2017b):

Tabel 1. Rukun dan Syarat Hiwalah

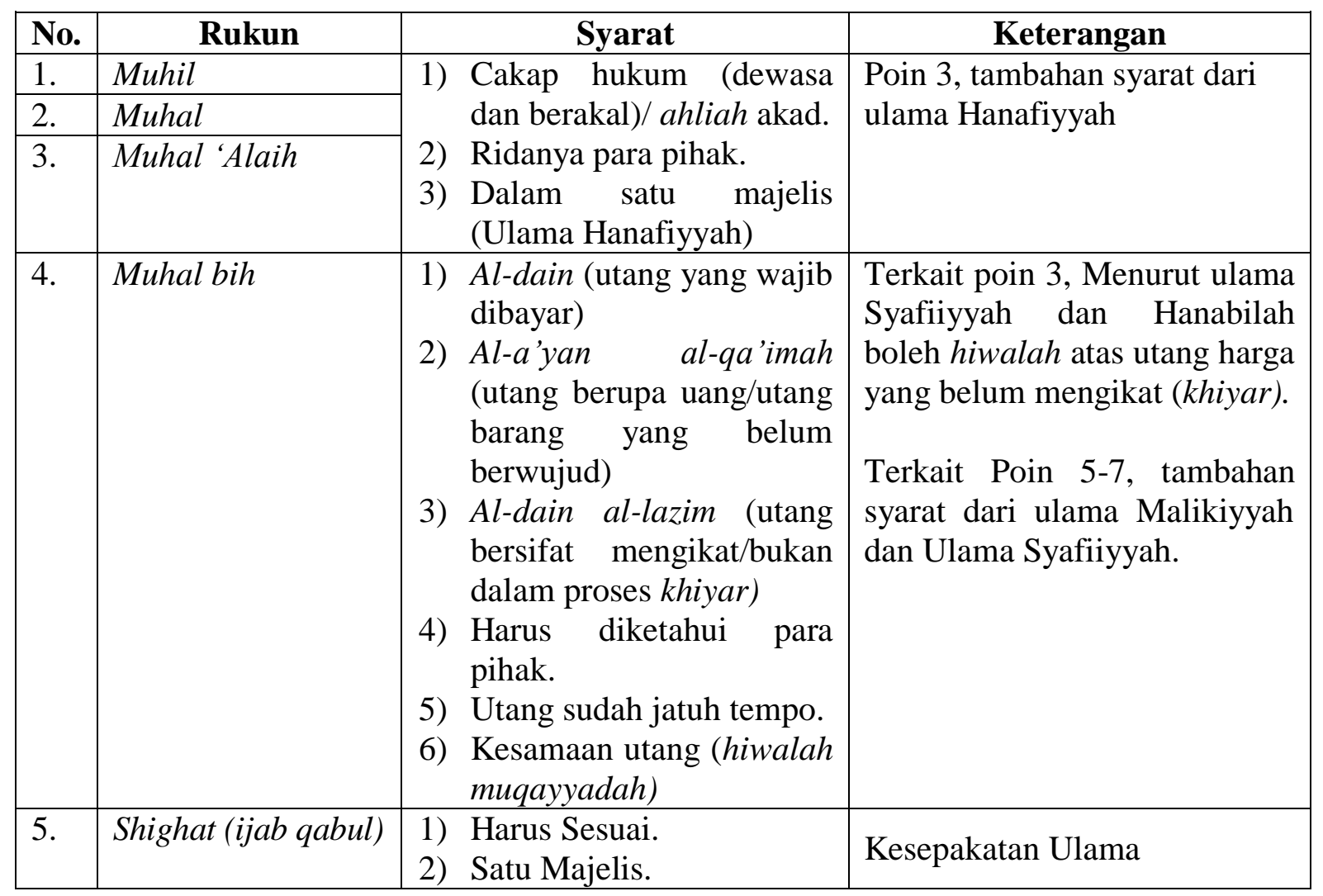




\section{Dasar Hukum Hiwalah}

Akad hiwalah merupakan salah satu bentuk muamalah antar manusia yang dibenarkan oleh Al-Qur'an, hadits Rasulallah SAW dan ketentuan ijma'. Berikut merupakan ayat yang dapat dijadikan landasan dalam melakukan transaksi menggunakan akad hiwalah, yaitu :

Artinya: "Dan jika (orang yang berhutang itu) dalam kesukaran, maka berilah tangguh sampai dia berkelapangan dan menyedekahkan (sebagian atau semua utang) itu lebih baik bagimu jika kamu mengetahuinya" (Q.S Al-Baqarah: 280).

Rasulallah S.A.W juga bersabda bahwa :

"Memperlambat pembayaran utang yang dilakukan oleh orang kaya merupakan perbuatan zalim. Jika salah seorang kamu dialihkan kepada orang yang mudah membayar utang, maka hendaklah ia beralih".

Selain itu, terdapat hadits lain yang juga meriwayatkan makna yang sama yaitu hadits yan di riwayatkan oleh Ahmad bin Hanbal, yaitu :

"Barangsiapa yang dialihkan kepada orang yang kaya, maka hendaklah diturutinya”.

Di samping itu, terdapat juga kesepakatan para ulama (Ijma') yang menyatakan bahwa tindakan hiwalah boleh dilakukan. Madzhab Hanafi membagi Hiwalah kepada beberapa pembagian. Ditinjau dari segi obyek akad, Hiwalah terbagi menjadi dua, yaitu:

1. Hiwalah al-haqq (pemindahan hak), terjadi apabila yang dipindahkan merupakan hak menuntut utang.

2. Hiwalah ad-dain (pemindahan utang), terjadi apabila yang dipindahkan itu adalah kewajiban untuk membayar utang.

Berdasarkan beberapa landasan hukum di atas, dapat diketahui bahwa akad hiwalah disyariatkan oleh agama islam dan diperbolehkan menerapkannya sehari-hari, karena dalam pelaksanaannya terdapat unsur maslahat bagi diri pribadi maupun orang lain yaitu berupa kemudahan dalam bermuamalah dan sikap saling tolongmenolong antar sesama manusia.
Pembagian Akad Hiwalah dan Hukumnya

Secara umum, akad hiwalah dapat dibedakan menjadi dua, yaitu (Syaikhu, Aryadi, \& Norwili, 2020): Pertama, Akad hiwalah Muayyadah. Hiwalah muqayyadah artinya akad hiwalah yang bersifat terikat. Contoh, Tuan Asep (muhal) memiliki piutang kepada tuan Bondan (muhil) dan tuan Bondan (muhal) memiliki piutang kepada tuan Cepi (muhil). Utang (muhal bih) tuan Bondan kepada tuan Asep jatuh tempo dan tuan Bondan tidak mampu membayarnya. Maka tuan Bondan meminta tuan Cepi (muhal 'alaih) untuk membayar utangnya ke tuan Asep dan tuan Asep menyetujuinya (adanya keterkaitan utang piutang tiga pihak).

Berkaitan dengan hal itu, terdapat perbedaan ketentuan hukum yaitu: pertama, Tuan Bondan memiliki kedudukan ganda, yaitu sebagai pihak yang memiliki utang kepada tuan Asep (muhil) dan sebagai pihak yang memiliki piutang kepada tuan Cepi (muhal). Begitu juga dengan kedudukan tuan Cepi, yaitu sebagai pihak yang memiliki utang kepada tuan Bondan (muhil) dan sebagai pihak yang memiliki kewajiban membayar utang tuan Bondan ke tuan Asep (muhal 'alaih).

Apabila kedudukan utang (muhal bih) tuan Cepi kepada tuan Bondan sama dengan utang tuan Bondan ke tuan Asep maka utang (muhal bih) tuan Bondan kepada tuan Asep lunas begitu juga utang (muhal bih) tuan Cepi kepada tuan Bondan. Namun apabila utang (muhal bih) tuan Bondan kepada tuan Asep lebih banyak dari pada utang (muhal bih) tuan Cepi kepada tuan Bondan. Maka tuan Bondan harus melunasi sisa utangnya kepada tuan Asep. Dan utang (muhal bih) tuan Cepi kepada tuan Bondan lunas. Sedangkan apabila sebaliknya, maka utang (muhal bih) tuan Bondan kepada tuan Asep lunas dan tuan cepi tetap harus membayar sisa utangnya (muhal bih) kepada tuan Bondan.

Kedua, Akad hiwalah muthlaqah. Artinya, akad hiwalah yang mutlak. Contoh, tuan Asep (muhal) memiliki piutang kepada tuan Bondan (muhil). Utang (muhal bih) tuan Bondan kepada tuan Asep jatuh tempo dan tuan Bondan tidak mampu membayarnya. 
Maka tuan Bondan meminta tuan Cepi (muhal 'alaih) untuk membayar utangnya ke tuan Asep dan tuan Asep menyetujuinya (utang piutang yang terjadi hanya dua pihak).

Kedudukan tuan Cepi merupakan pihak independen. Artinya, tidak terikat utang piutang kepada tuan Bondan. Sehingga adanya kerelaan dan kesepaktan dari tuan Cepi untuk melunasi utang tuan Bondan kepada tuan Asep. Hal itu merupakan sebuah perbuatan baik berupa tolong menolong. Sehingga pelunasan tersebut melahirkan pemindahan utang baru, yaitu tuan Bondan yang memiliki utang kepada tuan Asep beralih memiliki utang kepada tuan Cepi.

Dengan demikian, akad hiwalah dapat dikatakan sah dan utang muhil kepada muhal dikatakan lunas setelah muhal alaih membayar utang muhil kepada muhal. Namun apabila setelah adanya kesepakatan akad hiwalah di antara para pihak. Muhal 'alaih belum melunasi utang muhil kepada muhal dan mengalami kebangkrutan atau meninggal dunia (al-tawa) maka menurut jumhur ulama muhal tidak lagi menagih kepada muhil (berdasarkan pandangan teori pelepasan (al-ibra'). Adapun menurut ulama Hanafiyyah, apabila hal itu terjadi maka tetap muhal berhak menagih piutangnya kepada muhil (Berdasarkan teori penggabungan (aldzimmah) dan pelepasan (al-ibra') (Sahrani \& Abdullah, 2011).

Praktik akad hiwalah ini menurut sebagian ulama merupakan akad jual beli utang dengan utang (bai' dain bi dain) yang dikecualikan. Artinya, hukum jual beli tersebut haram dilakukan sedangkan akad hiwalah boleh dilakukan karena adanya alhajjah al-massah sebagai pengecualian dari akad jual beli yang dilarang (Mubarok \& Hasanudin, 2017b). Namun apabila melihat kedudukan adanya utang (dain) berbeda dengan skema jual beli dain bi dain. Di mana utang yang boleh dihiwalahkan adalah utang terhadap harta istihlaki (harta yang habis sekali pakai). Seperti utang (dain) yang berasal dari akad qardh, utang (dain) yang berasal dari jual beli, pembayaran ujrah yang dilakukan secara tidak tunai, sisa utang (dain) dalam pelunasan gadai, utang yang berasal dari pembagian bagi hasil yang ditangguhkan dan lain sebagainya. Dengan demikian, sejatinya kedudukan akad hiwalah merupakan akad pelengkap dari akad pokoknya yaitu al-uqud al-mudayanah.

\section{Tinjauan Umum Akad Kafalah \\ Definisi dan Dasar Hukum Kafalah}

Kafalah menurut kebahasaan memiliki makna al-dhamm (jaminan/pengamanan), hamalah (beban) dan za'amah (tanggungan) (Rusyid, n.d.). Para ulama dapat dibedakan menjadi dua kelompok dalam menentukan makna kafalah secara bahasa: Pertama, ulama Hanafiyyah dan Hanabilah memberi makna kafalah sebagai al-dhamm (menggabungkan kewajiban yang berutang sehingga menjadi utang penjamin). Kedua, ulama Syafiiyyah berpendapat bahwa kafalah memiliki makna al-iltizam (mengharuskan atau mewajibkan dirinya sendiri atas sesuatu yang sebenarnya bukan kewajibannya) (Al-Zuhayli, 2018).

Adapun menurut peristilahan, pendapat ulama dapat dikategorikan dalam dua pendapat, yaitu: Menurut ulama Hanafiyyah, kafalah adalah menggabungkan tanggungjawab mengenai penagihan atau penuntutan (hak) secara mutlak (Mubarok \& Hasanudin, 2017b). Sehingga ulama Hanafiyyah menggunakan kata kafalah dan membaginya menjadi dua, yaitu kafalah bi al-mal dan kafalah bi al wajh/ nafs). Sedangkan menurut jumhur ulama, kafalah adalah akad yang menetapkan iltizam hak yang tetap pada tanggungan (beban) orang lain atau menghadirkan zat suatu benda yang dibebankan atau menghadirkan badan orang yang berhak menghadirkannya (Al-Nawawi, n.d.-b). Ulama Malikiyyah menggunakan istilah dhaman dan membaginya menjadi dua, dhaman al-mal dan dhaman alwajh/nafs. Ulama Syafiiyyah hanya menggunakan istilah kafalah bi al-mal saja dan ulama Hanabilah menggunakan istilah dhaman untuk jaminan atas harta (dhaman al-mal) dan kafalah untuk istilah jaminan kesanggupan menghadirkan seseorang (kafalah bi al-nafs) dalam proses pengadilan (Mubarok \& Hasanudin, 2017b). 
Hukum Islam membolehkan akad kafalah untuk dilakukan sebagaimana syar'un man qablana (Syariat sebelum kita) dalam penggalan Al-Qur'an surah Yusuf: 72 bahwasanya ketika piala raja (sejenis cangkir) hilang para punggawa kerajaan mengumumkan sayembara, "barangsiapa yang menemukan (piala raja) akan mendapat bahan makanan seberat beban unta dan punggawa raja menjaminnya" (Departemen Agama RI, 2010). Hal itu ditegaskan juga dalam penggalan hadits $\mathrm{Abu}$ Dawud bahwasanya, "orang yang mejamin merupakan orang yang harus menanggung" (Abdurrahman, 2011). Adapun menurut ijma' umat Islam sepakat bahwa akad kafalah boleh dilakukan karena dibutuhkan oleh manusia dalam rangka membantu menghilangkan beban diri orang yang berutang (Al-Zuhayli, 2018). Selain itu juga, DSN/MUI menetapkan Fatwa Nomor 11 tahun 2000 tentang Kafalah.

Sehingga hikmah diberlakukannya akad kafalah adalah mendatangkan sikap tolong menolong, keamanan, kenyamanan dan kepastian dalam bertransaksi. Sebagaimana menurut Wahbah Al-Zuhayli yang dikutif Ghazaly menegaskan bahwa hikmah akad kafalah adalah untuk memperkuat hak, merealisasikan sikap tolong menolong antar sesama, mempermudah transaksi dalam pembayaran utang, harta dan pinjaman. Sehingga hal itu, memberikan ketenangan bagi orang yang berutang maupun orang yang memberikan utang (Ghazaly, Ihsan, \& Shidiq, 2018).

\section{Syarat dan Rukun kafalah}

Suatu akad pasti dapat dikatakan sah apabila memenuhi syarat dan rukunnya. Sehingga syarat hiwalah mengacu kepada rukun hiwalah yang terdiri dari: Para pihak (subjek) yang akan melahirkan syarat subjektif, objek akad (yang melahirkan syarat objek dan bentuk akad atau perjanjiannya. Hal itu akan dipaparkan sebagai berikut (Abdurahman, 2018):

Tabel 2. Rukun dan Syarat Kafalah

\begin{tabular}{|c|c|c|c|}
\hline No. & Rukun & Syarat & Keterangan \\
\hline 1. & Kafil (penjamin) & \multirow{3}{*}{$\begin{array}{l}\text { Cakap hukum (ahliah akad) } \\
\text { dan mampu melakukan } \\
\text { akad kafalah. Adanya } \\
\text { kerelaan atau kesepakatan } \\
\text { di antara para pihak. Harus } \\
\text { saling mengenal. }\end{array}$} & \multirow{5}{*}{$\begin{array}{l}\text { Kelima Rukun tersebut } \\
\text { merupakan pendapat jumhur } \\
\text { ulama selain ulama } \\
\text { Hanafiyyah. Menurut ulama } \\
\text { Hanafiyyah rukun kafalah } \\
\text { hanya pernyataan permintaan } \\
\text { (ijab) dan penawaran (qabul). }\end{array}$} \\
\hline 2. & $\begin{array}{l}\text { Makful } \\
\text { 'anhu/madin/ashil } \\
\text { (Terjamin) }\end{array}$ & & \\
\hline 3. & $\begin{array}{l}\text { Makful lahu/da'in } \\
\text { (Menerima } \\
\text { Jaminan) }\end{array}$ & & \\
\hline 4. & $\begin{array}{l}\text { Makful bih/al-dain } \\
\text { (objek/utang) }\end{array}$ & $\begin{array}{l}\text { Sesuatu yang menjadi } \\
\text { tanggung jawab ashil } \\
\text { (utang, barang dan jiwa). } \\
\text { Sesuatu yang mampu } \\
\text { ditunaikan. Utang yang } \\
\text { mengikat. }\end{array}$ & \\
\hline 5. & Shighat (ijab qabul) & $\begin{array}{l}\text { Akad harus sesuai (ijab dan } \\
\text { qabul). Harus pasti dan } \\
\text { tidak dikaitkan dengan } \\
\text { syarat tertentu. Harus } \\
\text { menunjukkan } \\
\text { pernyataan adanya } \\
\text { komitmen. }\end{array}$ & \\
\hline
\end{tabular}




\section{Pembagian Akad Kafalah}

Ragam akad kafalah dapat dikategorikan sebagai berikut (Mubarok \& Hasanudin, 2017b): Pertama, berdasarkan mahall (objek) nya terdiri dari:

1. Kafalah bi al-nafs yaitu jaminan terhadap jiwa. Artinya, kafalah untuk menghadirkan seseorang dalam proses pengadilan.

2. Kafalah bi al-mal yaitu jaminan terhadap harta. Terbagi menjadi tiga, yaitu:

a. kafalah bi al-dain (jaminan untuk menanggung utang seseorang dalam hal tidak mampu membayar utang pada saat jatuh tempo).

b. kafalah bi al- 'uhdah (jaminan terhadap kestabilan harga pasar dengan jaminan adanya subsidi).

c. kafalah bi al-taslim (jaminan terhadap barang yang dibutuhkan dapat diserahterimakan).

dari:

Kedua, berdasarkan sifatnya terdiri

1. Kafalah muthlaqah yaitu jaminan yang tidak terikat dengan syarat-syarat tertentu, baik berdasarkan teknik pembayaran utangnya, tempat maupun waktunya.

2. Kafalah muqayyadah yaitu jaminan yang terikat dengan waktu dan syarat tertentu. Kafalah muqayyadah terbagi menjadi tiga, yaitu:

a. kafalah berbatas waktu;

b. kafalah mu'allaq bi al-syart (jaminan yang tergantung kepada syarat tertentu); dan

c. kafalah mustaqbal (jaminan terhadap sesuatu di masa yang akan datang).

\section{Akibat Hukum}

Adanya akad kafalah (khusus akad kafalah bi al-mal) melahirkan beberapa ketentuan hukum. Pertama, hak tagih bagi makful lah yang sebelumnya ditujukan kepada ashil berpindah kepada kafil apabila ada kesepakatan bahwa yang dijamin (ashil) terbebas dari kewajiabn membayar utang. Namun jumhur ulama sepakat adanya akad kafalah tidak mengakibatkan terbebasnya pihak yang berutang (ashil) atas kewajibannya membayar utang. Sedangkan menurut Wahbah Al-Zuhayli yang dikutif Jaih Mubarok sama dengan pernyataan jumhur ulama (Mubarok \& Hasanudin, 2017b). Namun, apabila kesepakatan menjadikan pihak yang berutang (ashil) terbebas dari kewajibannya membayar utang. Maka secara substansi hal itu telah mengubah akad kafalah menjadi akad hiwalah (pemindahan utang).

Kedua, hak kafil untuk menagih utangnya kepada ashil. Kafil berhak menagih piutangnya kepada ashil dengan syarat akad kafalah yang dilakukan atas persetujuan pihak ashil. Apabila akad kafalah tanpa persetujuan pihak ashil maka kafil tidak berhak menagih. Hal itu disamakan dengan akad hibah (Al-Zuhayli, 2018).

Sebagaimana akad hiwalah, akad kafalah termasuk akad pelengkap dari akad pokoknya yaitu al-uqud al-mudayyanah. Kedudukannya hampir sama dengan akad hiwalah mutlaqah di mana kafil sebagai pihak yang independen tanpa adanya utang kepada ashil. Namun apabila pihak kafil mempunyai utang kepada ashil maka kedudukan penjaminan yang diakukan kafil sebagaimana langkah pelunasan utangnya kepada ashil dalam akad hiwalah. Adapun yang membedakannya adalah akad yang dilakukannya. Di mana akad kafalah boleh dilakukan sesudah pihak terjamin (ashil) mempunyai kewajiban utang terhadap makful lahu ataupun akan melakukan pinjaman atau hal lain yang dapat melahirkan utang.

\section{PEMBAHASAN DAN DISKUSI}

Tinjauan Analisis Akad Hiwalah dan akad Kafalah di Lembaga Keuangan Syariah (LKS): Sebuah Transformasi Akad

Akad hiwalah dan kafalah merupakan bagian dari akad tabarru' (sosial/tolong menolong). Karena membayarkan utang dan melakukan penjaminan merupakan salah satu bentuk dari ketaataan kepada Allah dan Rasul-Nya. Sehingga cukup bagi muhal 'alaih dan kafil mendapatkan pahala dari Allah SWT atas kesediannnya membatu muhil dan ashil. 
Namun dalam perkembangannya, kedua akad tersebut mengalami transformasi dalam memenuhi kebutuhan masyarakat. Transformasi merupakan perubahan yang mendalam sampai kepada perubahan nilai kultural (Hakim, 2011). Baik perubahan itu mencangkup secara keseluruhan ataupun sebagiannya. Di mana kedua akad tersebut yang hukum asalnya merupakan akad tabarru' beralih menjadi akad mu'awadhat, yaitu akad yang awalnya merupakan domain akad yang bersifat sosial/tolong menolong berubah menjadi akad yang merupakan domain akad yang bersifat bisnis/mencari keuntungan.

Perkembangan transformasi tersebut beriringan dengan perkembangan LKS, baik dalam bentuk lembaga perbankan syariah maupun lembaga nonperbankan syariah. Di mana lembaga tersebut merupakan lembaga alternatif dan bisa dikatakan sebagai lembaga keuangan yang berdiri kokoh sebagai solusi dalam transaksi keuangan yang sesuai dengan prinsip syariah. Adapun transpormasi tersebut adalah transpormasi dari akad hiwalah (tabarru') menjadi akad hiwalah bi al-ujrah (mu'awadhat) dan transpormasi akad kafalah (tabarru') menjadi akad kafalah bi al-ujrah (mu'awadhat). Kedua transpormasi akad tersebut akan dipaparkan sebagai berikut:

Akad hiwalah bi al-ujrah dan akad kafalah bi al-urjah keberlakuan penerapannya di Indonesia berdasarkan Fatwa DSN/MUI Nomor 57 tahun 2007 tentang letter of credit (L/C) dengan akad kafalah bi ujrah dan Fatwa DSN/MUI Nomor 58 tahun 2007 tentang hiwalah bi ujrah. Dalam kedua fatwa tersebut Majelis Ulama Indonesia selain mengacu kepada ketentuan Al-Qur'an dan Al-Hadits (nash qath'i) juga berpacu kepada pendapat para ulama (tahlili) yaitu:

Pendapat ulama yang melarang, antara lain: Jumhur ulama berpendapat bahwa kesepakatan mengenai ujrah atas jasa kafalah termasuk riba (qardh), sehingga haram hukumnya (Mubarok \& Hasanudin, 2017b). Pendapat ulama yang membolehkan, antara lain:
1. Mushthafa' Abdullah Al-Himsyari yang dikutif oleh Syaikh 'Athiyyah Shaqr dalam kitab ahsan al-kalam fi al-fatwa wa al-ahkam memaparkan bahwa ujrah atas jasa hiwalah dan kafalah disandarkan kepada ujrah atas jasa jah (dignity, kewibawaan) dan ujrah atas natijah (prestasi) dalam akad ju'alah yang menurut mazhab syafii dibolehkan mengambil ujrah atas jasa tersebut.

2. Pendapat sejumlah ulama dalam kitab al-mausu'ah al- 'ilmiyyah li al-bunuk alIslamiyyah yang dikutif Jaih Mubarok menyatakan bahwa sejumlah ulama yang membolehkan adanya ujrah atau $j u$ 'l atas jasa pemjaminan sebagaimana bolehnya mengambil ujrah atas jasa keagamaan (tabarru' atau ibadah).

3. Baqir Shadr dalam kitab al-bunuk allaribawi fi al-Islam yang juga dikutif Jaih Mubarok menyatakan bolehnya mengambil ujrah atas jasa kafalah. Di mana ujrah yang diterima merupakan kompensasi atas penjaminan yang dilakukan sekaligus risiko yang ditanggung oleh kafil (Mubarok \& Hasanudin, 2017b).

Kebolehan akad kafalah bi al-ujrah tersebut menjadi kebolehan atas hiwalah bi al-ujrah. Hal itu bisa dilihat dalam substansi dasar hukum penetapan fatwa kafalah lebih dulu dari penetapan fatwa hiwalah. Adapun melihat pendapat ulama yang membolehkan, kedua akad tersebut di samakan dengan akad ijarah 'ala al-asykhash (ijarah jasa). Sehingga boleh mengambil upah atas jasa hiwalah (pengalihan utang) dan kafalah (penjaminan utang). Hal itu ditegaskan dalam hadits yang diriwayatkan al-Nasa'i bahwasanya Rasulullah Bersabda, "Barang siapa mempekerjakan pekerja, maka beritaukanlah upahnya" (Abdurrahman, 2011). Substansi hadits tersebut juga dijadikan dasar penetapan kaidah fiqh yang dipaparkan Ibnu Qudamah dalam kitab AlMughni yaitu "Apabila pekerja/karyawan telah mencurahkan tenaganya maka ia berhak mendapatkan upahnya" (Al-Syarbini, 1997). Adapun ketentuan khusus dalam kedua fatwa tersebut antara lain: Dalam 
ketentuan akad Fatwa DSN/MUI Nomor 58 tahun 2007 tentang Hiwalah bi al-Ujrah menyatakan bahwa akad hiwalah bi al-ujrah hanya berlaku bagi hiwalah muthlaqah yaitu hiwalah di mana kedudukan muhal alaih adalah pihak independen yang tidak memiliki utang kepada muhil. Sehingga dalam praktik di lapangan, LKS sebagai muhal 'alaih membantu nasabahnya (muhil) untuk membayarkan utangnya kepada muhal (baik perorangan atau LKS yang lain atau bahkan LKK). Akad hiwalah bi al-ujrah dilakukan secara tertulis yang mencantumkan hak dan kewajiban para pihak, serta ujrah yang disepakati, termasuk berpindahnya penagihan dari muhal kepada muhal 'alaih. Selain itu juga, LKS boleh memberikan sebagai fee/keuntungan kepada shahibu almal. Dengan kata lain, LKS membayar utang nasabah (muhil) dengan menggunakan dana dari proses penghimpunan dana dari nasabah lain.

Sedangkan dalam ketentuan akad Fatwa DSN/MUI Nomor 57 tahun 2007 tentang Letter of Credit dengan akad Kafalah bi al-Ujrah menyatakan bahwa kafalah bi alujrah yang di berikan LKS kepada nasabah merupakan penjaminan terhadap utang piutang dalam transaksi ekspor dan impor. Hal itu membuktikan bahwa kafalah bi alujrah dilakukan terhadap kafalah bi al-mal (pejaminan terhadap harta). Adapun penjaminan tersebut harus disertai dengan ujrah.

Ketentuan kedua fatwa tersebut juga didasarkan kepada kebutuhan nyata (alhajjah/al-dharurah) dari pihak muhil dan juga ashil yang tidak menemukan pihak muhal 'alaih dan kafil yang melakukan tolong menolong secara sukarela melainkan harus dengan ujrah tertentu. Sehingga kedua akad tersebut boleh dilakukan dengan menentukan ujrah tertentu. Di mana penentuan ujrah yang disepakati telah membuat pihak muhal alaih dan kafil mau membantu pihak muhil dan ashil. Secara tidak langsung, hal itu menghilangkan kemudaratan yang tidak diinginkan antara pihak muhil dan ashil dengan pihak muhal dan makful lah (terjadinya perpecahan akibat muhil dan ashil tidak mampu membayar utang). Dengan demikian, sejatinya kedua akad tersebut boleh dilakukan dengan memperhatikan tingkat kemaslahatan di antara para pihak yang berakad, baik antara muhil, muhal dan muhal 'alaih dalam akad hiwalah bi al-ujrah dan antara kafil, ashil dan makful lah dalam akad kafalah bi al-ujrah.

\section{KESIMPULAN}

Transformasi akad tabarru' (hiwalah dan kafalah) menjadi akad mu'awadhat (hiwalah bi al-ujrah dan kafalah bi al-ujrah) berdasarkan fatwa DSN/MUI yang mengacu kepada kebutuhan masyarakat (LKS dan Nasabah) yang tetap memperhatikan ketentuan nash dan tingkat kemaslahatan. Sehingga secara tidak langsung, DSN/MUI selalu menggunakan kaidah "Jalbu alMashalih wa Dar al-Mafashid" (meraih maslahat dan menolak mafsadat). Di mana apabila kedua akad tersebut tidak diberlakukan. Maka para muhil dan ashil merasa kesulitan dalam menyelesaikan masalahnya karena tidak dapat menemukan muhal 'alaih dan juga kafil yang membantu secara sukarela bahkan terancam terjadinya perpecahan dengan muhal dan makful lah akibat tidak dapat memenuhi kewajibannya (membayar utang). Adapun kedua akad tersebut dipraktikkan dalam produk pengalihan/penjaminan utang atau pembiayaan yang dilakukan LKS sebagai lembaga independen terhadap nasabah yang memiliki utang kepada pihak lain, baik kepada perorangan, LKS lain bahkan kepada LKK sekalipun.

\section{DAFTAR PUSTAKA}

Abdurahman, R. (2018). Pengantar Fiqh Muamalah. Bandung: Insan Rabbani.

Abdurrahman, M. H. (2011). Mausuah Ahadits Ahkam Al-Muamalah AlMaliyyah. Riyadh: Dar Al-kautsar.

Ad-Dardir. (n.d). Asy-Syarh al-Kabir, Jilid III, dan Ibnu Qudamah, Al-Mugni, Jilid IV, h. 528, asySyarbaini al-Khathib, Mugni al-Muhtaj, jilid II.

Al-Jaziri, A. (n.d.). Al-Fiqh 'Ala AlMadzahib Al-Arba'ah. Beirut: Dar al- 
Fikr.

Al-Nawawi, M. (n.d.-a). Al-Majmu’ Syarah Al-Muhadzdzab, Jilid 16, (Penerjemah) Muhammad Najih AlMuthi'. Jakarta: Pustaka Azzam.

Al-Nawawi, M. (n.d.-b). Al-Majmu' Syarah Al-Muhadzdzab, Jilid 17, (Penerjemah) Muhammad Najih AlMuthi'. Jakarta: Pustaka Azzam.

Al-Syarbini, S. K. (1997). Mughni alMuhtaj. Beirut: Darul Makrifah.

Al-Zuhayli, W. (2018). Al-Fiqh al-Islami wa Adillatuhu, Jilid 6, (Penerjemah) Abdul Hayyie al-Kattani dkk. Kuala Lumpur: Darul Fikir.

Antonio, M. S. (2018). Bank Syariah dari Teori ke Praktik. Depok: Gema Insani.

Aziz, J. A. (2012). Transformasi Akad Muamalah Klasik dalam Produk Perbankan Syariah. Al-Tahrir: Jurnal Pemikiran Islam, 12(1), 21-41. https://doi.org/10.21154/altahrir.v12i1.45

Departemen Agama RI. (2010). Al-Quran dan Terjemahnya. Bandung: Syaamil Qur'an.

Ghazaly, A. R., Ihsan, G., \& Shidiq, S. (2018). Fiqh Muamalah. Jakarta: Prenada Media Group.

Hakim, A. A. (2011). Fiqih Perbankan Syariah: Transpormasi Fiqh Muamalah ke dalam Peraturan Perundang-undangan. Bandung: PT. Reflika Aditama.

Hasan, A. F. (2018). Figh Muamalah dari Klasik hingga Kontemporer (Teori dan Praktek). Malang: UIN Maliki Press.

Huda, N. (2015). Perubahan Akad Wadi'ah. Economica: Jurnal Ekonomi Islam, 6(1), 129-154. https://doi.org/10.21580/economica.20 15.6.1.789

Kusumastuti, A. S., \& Rahmawati, R. (2019). Tinjauan Hukum Islam Terhadap Akad Pada Aplikasi Go-Food di Madiun. AlMustashfa: Jurnal Penelitian Hukum Ekonomi Islam, 4(2), 200-211. https://doi.org/10.24235/jm.v4i2.3879

Miles, M. B., \& Huberman, A. M. (1984). Qualitative Data Analysis (a Source book of New Methods). Beverly Hills: Sage Publications.

Mubarok, J., \& Hasanudin. (2017a). Fikih Mu'amalah Maliyyah: Prinsip-Prinsip Perjanjian. Bandung: Simbiosa Rekatama Media.

Mubarok, J., \& Hasanudin. (2017b). Fiqh Mu'amalah Maliyyah: Akad Tabarru'. Bandung: Simbiosa Rekatama Media.

Riyadi, S., \& Hilyatin, D. L. (2021). Transformasi Ekonomi Islam dalam Sistem Ekonomi Kerakyatan. AlMustashfa: Jurnal Penelitian Hukum Ekonomi Islam, 6(1), 43-56. https://doi.org/10.24235/jm.v6i1.8100

Rozali, A. (2020). Transformasi Akad Perbankan Syariah dalam Pembentukan Hukum Perikatan Nasional. Jurnal Wawasan Yuridika, 4(1), 31-46. https://doi.org/10.25072/jwy.v4i1.320

Rusyid, I. (n.d.). Bidayah al-Mujtahid wa Nihayah al-Muqtashid, Jilid 2, (Penerjemah) Ahmad Abu Al-Majdi. Jakarta: Pustaka Azzam.

Sahrani, S., \& Abdullah, R. (2011). Fikih Muamalah. Bogor: Ghalia Indonesia.

Sudiarti, S. (2018). Fiqh Muamalah Kontemporer. Medan: UIN-SU Press.

Syahpawi, S. (2012). Hiwalah sebagai solusi dalam mengatasi kredit macet dalam perbankan syariah. IQTISHADUNA: Jurnal Ilmiah Ekonomi Kita, 1(2), 165-175. Retrieved from https://ejournal.stiesyariahbengkalis.ac .id/index.php/iqtishaduna/article/view/ 12

Syaikhu, Aryadi, \& Norwili. (2020). Fikih Muamalah: Memahami Konsep dan Dialektika Kontemporer. Yogyakarta: K-Media.

Syarqawie, F. (2015). Fikih Muamalah. Banjarmasin: IAIN Antasari Press.

Witro, D. (2019). Praktek Jual Beli Parang dengan Cara Penumpukan untuk Meningkatkan Harga di Desa Koto Padang Perspektif Hukum Islam. AlQisthu: Jurnal Kajian Ilmu-Ilmu Hukum, 17(1), 34-40. https://doi.org/10.32694/010710 
Witro, D. (2021). Qaidah furu' fi al-hiwalah: Sebuah tinjauan umum. Qawãnïn: Journal of Economic Syaria Law, 5(1), $1-12$.

https://doi.org/10.30762/qawanin.v5i1 .2897

Witro, D., Nuraeni, N., \& Januri, M. F. (2021). Classification of Aqad in Sharia Economic Law. Nurani, 21(1), 55-68.

https://doi.org/10.19109/nurani.v21i1. 8387 